\title{
Enhanced Delignification Selectivity of Alkali-Oxygen Pulping by Wet-Storage Pretreatment with Bleaching Wastewater
}

\author{
Bing Sun, ${ }^{a}$ Yingzhen Shan, ${ }^{\mathrm{a}}$ Yuxin Liu, ${ }^{\mathrm{a}, *}$ and Zhen Shang ${ }^{\mathrm{b}}$
}

\begin{abstract}
Wet-storage is the most common way to maintain sugarcane bagasse in the pulping and paper-making industry, although there are few studies focused on the selectivity of delignification in pulping for bagasse treated by wet-storage. In this study, wet-storage of bagasse was carried out before alkali-oxygen pulping. The influence of wetstorage pretreatment on the chemical compositions, morphology of bagasse, and the consumption of $\mathrm{NaOH}$ in alkali impregnated bagasse meal were investigated. The wet-storage of bagasse resulted in significant improvement in delignification selectivity of alkali-oxygen pulping. After the bagasse was pretreated by wet-storage with bleaching water, the screened yield and crystallinity of the resulting alkali-oxygen pulp were increased.
\end{abstract}

Keywords: Bagasse; Wet-storage pretreatment; Alkali-oxygen pulping; Delignification selectivity

Contact information: a: Faculty of Chemical Engineering, Kunming University of Science and Technology, Kunming 650500, China; b: Tianjin Key Laboratory of Pulp and Paper, Tianjin University of Science and Technology, Tianjin 300457, China; *Corresponding authors: yuxinliukm@163.com

\section{INTRODUCTION}

Bagasse is a plentiful agricultural waste in Brazil, India, China, and other countries (Martínez et al. 2003). With the shortage of wood fiber in China, bagasse plays an important role in the paper-making industry (Xu 2001; Sridach 2010) due to its fiber composition and excellent properties (Vallejos et al. 2012; Rocha et al. 2012; $\mathrm{Fu}$ et al. 2013). The application of bagasse in the pulping and paper-making industry greatly alleviates the shortage of raw materials. In fact, bagasse pulping has attracted much attention from researchers (Khristova et al. 2006; Ogunsile et al. 2010; Khakifirooz et al. 2012; Li et al. 2015). Bagasse pulping has been carried out mostly using the soda, sulfate, and neutral sulfite methods. However, industrial processes for bagasse pulp production face several problems such as high cooking temperature, low pulp yields, and environmental pollution (Rainey et al. 2004; Yue et al. 2016).

Alkali-oxygen pulping is a particularly adequate method for bagasse (Chen et al. 1994; Vilay et al. 2008) due to the injection of oxygen before the pulping process. It helps delignification of fibrous raw materials and reduces the chloronome groups in the resulting pulp. Based on the mechanism of alkali-oxygen pulping, permeation enhancement of cooking liquor in bagasse is one of the keys to improve the delignification selectivity in alkali-oxygen pulping (Zhang and Chen 2007; Yue et al. 2016). Efficient alkali impregnation by pretreatments is beneficial for uniform pulping and shortening cooking time (Gullichsen and Sundqvist 1995; Malkov et al. 2001). The pretreatment methods investigated for bagasse include steam explosion (Martín et al. 2002; Sendelius 2005; Hernández-Salas et al. 2009), liquid hot water (Laser et al. 2002), peracetic acid (Teixeira et al. 1999), and ammonia water (Kurakake et al. 2001). Cui et al. (2012) reported that wet-storage is an easy and safe way to increase alkali impregnation. 
In this study, wet-storage pretreatments with bleaching wastewater (BW) and tap water (TW) were used for alkali-oxygen pulping of bagasse to enhance the delignification selectivity of alkali-oxygen pulping. The mechanism of the pretreatments and their effects on the delignification selectivity was investigated by the Brunner-Emmet-Teller (BET) method, scanning electronic microscopy (SEM), alkali impregnation and chemical composition of pretreated bagasse, and X-ray diffraction (XRD) of the resulting pulp.

\section{EXPERIMENTAL}

\section{Materials and Methods}

Sugarcane bagasse was provided by the Yunnan Xinping Nan'en Sugar and Paper Co., Ltd. (Yunnan province, China). Air-dried and de-pithed bagasse was stored in sealed plastic bags. Other chemical reagents were analytical grade and made in China.

\section{Wet-storage pretreatment of bagasse}

Bleaching wastewater (BW) from the OP bleaching stage was provided by Yunnan Xinping Nan'en Sugar and Paper Co., Ltd. (Yunnan province, China). A total of $1.0 \mathrm{~kg}$ bagasse (based on over dried bagasse) was pretreated with BW and tap water (TW) at the ratio of solid to liquor 1:6 in $16 \mathrm{~L}$ cubic container for 8 and 16 days, respectively. The pretreated bagasse was washed by tap water until it reached neutral $\mathrm{pH}$ and then air-dried. The relevant chemical compositions were determined according to TAPPI standards T4 wd-75 (1975), T17 wd-70 (1970), T13 wd-74 (1974), and T19 wd-71 (1971). The solid content of the permeate was determined according to TAPPI T692 om-04 (2004).

\section{BET and SEM of the wet-storage pretreated bagasse}

The samples were dried in vacuum at $120^{\circ} \mathrm{C}$ for $2 \mathrm{~h}$ before testing. The specific surface area and pore size of the pretreated bagasse were measured by the BrunauerEmmett-Teller analysis (BET) of nitrogen adsorption isotherms (JW-BK222, Specific Surface and Pore Size Instruments, Beijing, China). The morphologies of the pulps and pretreated bagasse were observed by a tungsten filament scanning electron microscope (SEM) (VEGA-3SBH, Tescan Corporation, Brno, Czech Republic). The crystallinity of pretreated bagasse was tested by X-ray diffraction analysis (XRD) (DMAX-2500, Rigaku, Tokyo, Japan) at a generator voltage of $40 \mathrm{kV}$, tube current of $40 \mathrm{~mA}$, divergence slit of $0.19 \mathrm{~mm}$, continuous scan of scan range of $10^{\circ}$ to $40^{\circ}$, scan step size of $0.01^{\circ}$, and scan rate of $7 \mathrm{~s} / \mathrm{step}$.

\section{Alkali impregnation of bagasse}

The alkali impregnation of pretreated bagasse (10.0 g, based on oven-dried bagasse) was performed in a $500 \mathrm{~mL}$ flask in water bath at $80{ }^{\circ} \mathrm{C}$ with alkali charge of $23 \%$ and bagasse consistency of $12 \%$, and the alkali impregnation times were $5,10,15$, 20 , and $60 \mathrm{~min}$. After alkali impregnation was completed, the slurry was filtered immediately, and the filtered liquor was collected. The alkali concentration in black liquor was determined according to TAPPI T625 cm-14 (2014).

Pretreated bagasse was pulverized by micro plant sample mill (FZ102, Ke heng Co., Beijing, China), and then screened to obtain the 40/60 mesh fraction. The $\mathrm{NaOH}$ concentration of the spent liquor was used to calculate the amount of $\mathrm{NaOH}$ consumption during alkali impregnation, according to the following equation: 


$$
\mathrm{M}=\frac{\left(C_{1} V_{1}-V_{2} C_{2}\right) * 100}{m_{0}}
$$

where $M$ is the $\mathrm{NaOH}$ consumption in the alkali impregnation in $\mathrm{g} / 100 \mathrm{~g}$ oven-dry test sample, $V_{1}$ is the initial volume of $\mathrm{NaOH}(\mathrm{L}), C_{1}$ is the initial concentration of $\mathrm{NaOH}$ $(\mathrm{g} / \mathrm{L}), V_{2}$ is the liquid volume after alkali impregnation $(\mathrm{L}), C_{2}$ is the concentration of $\mathrm{NaOH}$ after alkali impregnation $(\mathrm{g} / \mathrm{L})$, and $m_{0}$ is the weight of the dried bagasse $(\mathrm{g})$.

\section{Alkali-oxygen pulping}

The cooking parameters of alkali-oxygen pulping were as follows: $\mathrm{NaOH}$ charge, $23 \%$ (based on over dried bagasse); $\mathrm{MgSO}_{4}$ charge, $0.5 \%$ (based on oven-dried bagasse); bagasse consistency, $12 \%$; initial oxygen pressure, $0.6 \mathrm{MPa}$; and the maximum temperature, $100{ }^{\circ} \mathrm{C}$ for $3 \mathrm{~h}$.

All resulting pulps were washed by tap water and screened by $0.20 \mathrm{~mm}$ sieve plate. The screened yield was determined gravimetrically on the samples following drying at $105 \pm 2{ }^{\circ} \mathrm{C}$ for $8 \mathrm{~h}$. The Kappa number and intrinsic pulp viscosity were determined according to TAPPI T236 om-13 (2013) and T230 om-13 (2013), respectively. The test of alkali-oxygen pulp's crystallinity was the same as for bagasse.

\section{RESULTS AND DISCUSSION}

\section{Proposed Concept of Enhancing Alkali Impregnation Effectiveness By Wet-Storage Pretreatment}

Figure 1 presents the hypothetical mechanism for improving alkali-oxygen delignification selectivity by wet-storage pretreatment. The residual chemicals in OP bleaching wastewater (BW) had an effect on dissolving small molecular substances from bagasse, which provided nutrients for the growth and reproduction of microorganisms from the inoculated bagasse during wet-storage process. The effect of BW and microorganisms on bagasse fiber improved the dissolution of some lignin small molecular and formation of porous structure of bagasse fiber during the wet-storage pretreatment. Regarding the alkali-oxygen pulping process, with the formed porous structure, more cooking liquid permeated in the inner cell wall structure of bagasse and reacted with lignin. The selectivity and efficiency of delignification were increased by the enhanced liquid permeability, which led to the improvement in pulping.

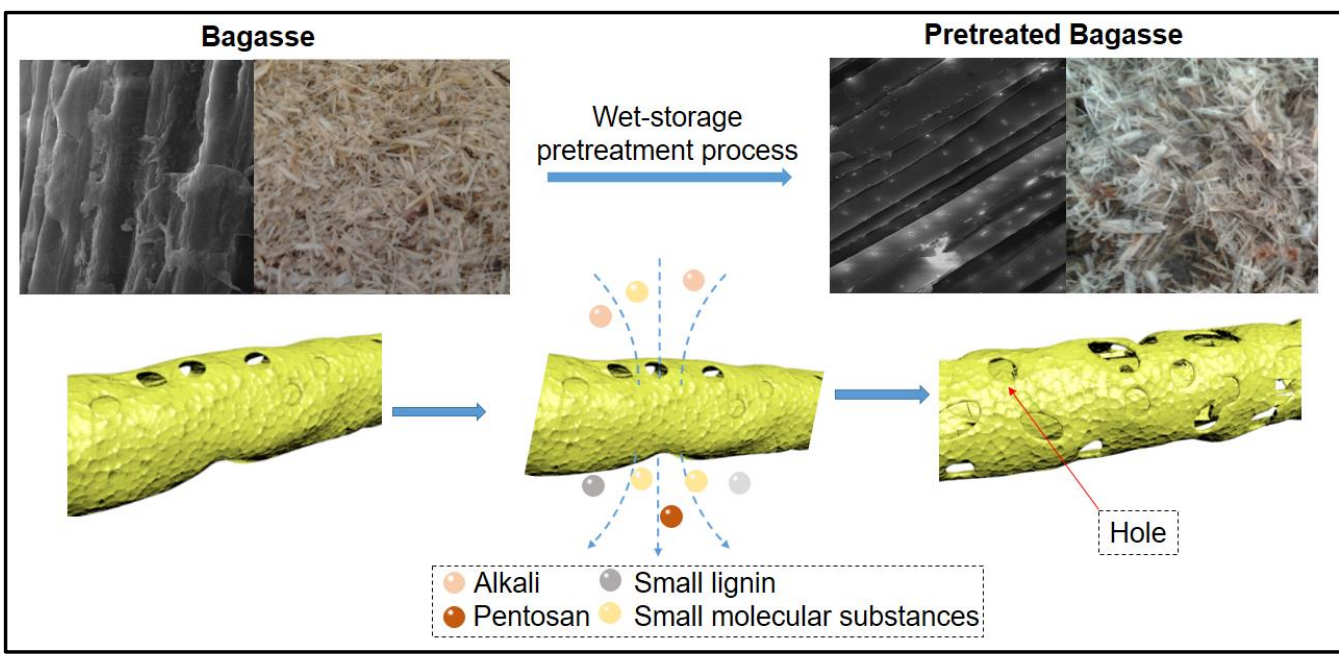

Fig. 1. A schematic illustration of mechanism for wet-storage pretreatment improved the delignification selectivity of alkali-oxygen pulping 


\section{Effect of Wet-storage Pretreatment on the Pore Diameter of Bagasse}

The effect of wet-storage on the porosity and average pore size of the bagasse raw materials is shown in Table 1 and Fig. 2. With the wet-storage time extended, the average pore size of BW reached the maximum $13.2 \mathrm{~nm}$ at the $16^{\text {th }}$ day; the average pore size $11.5 \mathrm{~nm}$ of TW was less than that of un-pretreated bagasse. New pores gradually appeared, and the original small aperture pores $(\leq 10 \mathrm{~nm})$ gradually transformed into large apertures pores (10 to $50 \mathrm{~nm}$ or $\geq 50 \mathrm{~nm}$ ) with the increasing pretreatment time. The changes in pore size and pore size distribution provided possibilities for the enhancing the penetration of the cooking liquor.

Table 1. Effect of Wet-storage Pretreatment on the Pore Size Distribution of Bagasse

\begin{tabular}{|c|c|c|c|c|}
\hline \multirow{2}{*}{$\begin{array}{c}\text { Wet-storage } \\
\text { Pretreatment Time } \\
\text { (days) }\end{array}$} & \multirow{2}{*}{$\begin{array}{c}\text { Pretreatment } \\
\text { Method }\end{array}$} & \multicolumn{3}{|c|}{ Pore Size Distribution (\%) } \\
\cline { 3 - 5 } & & $\leq 10 \mathrm{~nm}$ & 10 to $50 \mathrm{~nm}$ & $\geq 50 \mathrm{~nm}$ \\
\hline Un-pretreated & - & 49.4 & 26.4 & 24.1 \\
\hline \multirow{2}{*}{8} & BW & 47.0 & 28.8 & 24.2 \\
\cline { 2 - 5 } & TW & 58.4 & 28.7 & 12.9 \\
\hline \multirow{2}{*}{16} & BW & 46.4 & 28.2 & 25.4 \\
\cline { 2 - 5 } & TW & 51.3 & 28.7 & 20.0 \\
\hline
\end{tabular}

The above results demonstrate that the wet-storage pretreatment has an important impact on the structure of bagasse. It should be noted that the pore size and pore volume were increased resulting from the dissolution of small molecules. Furthermore, the increase of average pore size is beneficial to retaining more alkali liquor, improving fiber swelling ability and fiber quality.

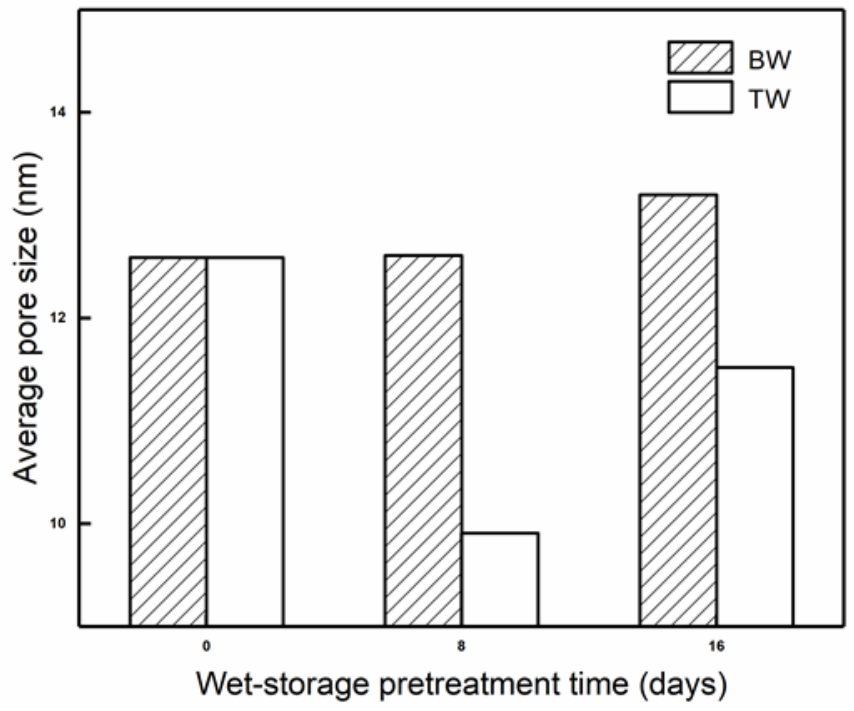

Fig. 2. Effect of wet-storage pretreatment on the average pore size of bagasse

\section{Effect of Wet-storage Pretreatment on the Alkali Impregnation Effectiveness of Bagasse Meals}

Alkali impregnation is the key factor of the pulping process, and it involves chemical reactions and swelling that occurs during penetration (Zanuttini et al. 2003). Table 2 shows that the amount of $\mathrm{NaOH}$ consumption increased with the extended of wet-storage pretreatment time, indicating an enhanced alkali impregnation. 
Table 2. Effect of Wet-storage Pretreatment on the Amount of $\mathrm{NaOH}$ Consumption of The Alkali Impregnated Bagasse Meal

\begin{tabular}{|c|c|c|c|c|c|c|}
\hline \multirow{2}{*}{$\begin{array}{c}\text { Wet-storage } \\
\text { Pretreatment }\end{array}$} & \multirow{2}{*}{$\begin{array}{c}\text { Pretreatment } \\
\text { Time } \\
\text { (days) }\end{array}$} & \multicolumn{5}{|c|}{$\begin{array}{c}\text { NaOH Consumption (g/100g o.d. samples ) at } \\
\text { Different Alkali Impregnation Time }\end{array}$} \\
\cline { 3 - 8 } & & $5 \mathrm{~min}$ & $10 \mathrm{~min}$ & $15 \mathrm{~min}$ & $20 \mathrm{~min}$ & $60 \mathrm{~min}$ \\
\hline Un-pretreated & - & 3.36 & 4.98 & 5.21 & 5.49 & 6.07 \\
\hline \multirow{2}{*}{8} & BW & 7.86 & 8.39 & 7.98 & 8.20 & 9.99 \\
\cline { 2 - 7 } & TW & 3.68 & 5.16 & 5.49 & 5.67 & 5.77 \\
\hline \multirow{2}{*}{16} & BW & 8.97 & 9.14 & 9.23 & 9.76 & 10.93 \\
\cline { 2 - 7 } & TW & 3.60 & 7.10 & 7.57 & 8.13 & 8.42 \\
\hline
\end{tabular}

Taking the alkali impregnation time of $60 \mathrm{~min}$ as an example, when the wetstorage pretreatment time was prolonged to the $16^{\text {th }}$ day, the amount of $\mathrm{NaOH}$ consumption increased from $6.07 \mathrm{~g} / 100 \mathrm{~g}$ (un-pretreated sample) to $10.93 \mathrm{~g} / 100 \mathrm{~g}$ treated by BW, and increased to $8.42 \mathrm{~g} / 100 \mathrm{~g}$ treated by TW. This phenomenon occurred because the BW with chemicals dissolves small molecular substances from bagasse, and the dissolved small molecular substances are good for the growth and reproduction of microorganisms, compared with TW. Simultaneously, the amount of $\mathrm{NaOH}$ consumption of bagasse increased with the time extension of wet-storage pretreatment. For the bagasse pretreated on the $16^{\text {th }}$ day by $\mathrm{BW}$, the amount of $\mathrm{NaOH}$ consumption was increased by $8.9 \%$ at the early stage of alkali impregnation ( $5 \mathrm{~min}$ to $20 \mathrm{~min}$ ), and increased by $12.2 \%$ at the late stage $(20 \mathrm{~min}$ to $60 \mathrm{~min}$ ). A possible reason can be explained as follows: under the condition of natural inoculation, microbes take full advantage of bagasse and dissolved substances during the wet-storage pretreatment. More importantly, naturally inoculated microbes degrade and utilize the dissolved small molecular lignin. Therefore, wet-storage pretreatment could enhance the subsequent alkali impregnation effectiveness of bagasse in alkali-oxygen pulping.

\section{Effect of Wet-storage Pretreatment on the Chemical Composition of Bagasse}

The chemical composition analysis is the most common method to evaluate the influence of the wet-storage pretreatment on fiber raw material (Zhu et al. 2005). The chemical composition of bagasse in the wet-storage pretreatment is shown in Table 3. The content of the $1 \% \mathrm{NaOH}$ extract of the raw material can be used to determine if the deterioration or decay of raw material is due to the action of oxidation or bacteria. In the whole wet-storage pretreatment process (16 days), the content of the $1 \% \mathrm{NaOH}$ extract showed a trend of increasing first and then decreasing. Thus, different substances were dissolved with the increasing pretreatment time. The content of cellulose showed a trend of decreasing but was maintained at around 52\%; this result indicated that part of the cellulose was consumed as nutrients. The content of lignin decreased at first and then slightly increased. This may be due to the fact that some lignin had been exposed and dissolved, which would increase delignification selectivity of subsequent pulping more or less. Combined with the results of the porosity change of the fibers, this data showed that chemicals of BW improved the aperture of bagasse with little effect on its chemical composition.

As shown in Fig. 3, the crystallinity of bagasse pretreated by BW or TW was increased to $13.4 \%$ (from $32.8 \%$ to $37.2 \%$ ) and $11.6 \%$ (from $32.8 \%$ to $36.6 \%$ ), respectively, at the $16^{\text {th }}$ day. The change of crystallinity might be due to the effect on the change of chemical compositions by wet-storage pretreatment. Small molecular substances are dissolved by residual chemicals and microorganisms, which formed porous structures in bagasse fiber and the increased crystallinity of pretreated bagasse. 
Table 3. Chemical Composition Analysis of Bagasse by Wet-Storage Pretreatment

\begin{tabular}{|c|c|c|c|c|c|}
\hline $\begin{array}{c}\text { Wet-storage } \\
\text { Pretreatment } \\
\text { Time } \\
\text { (days) }\end{array}$ & $\begin{array}{c}\text { Pretreatment } \\
\text { Method }\end{array}$ & $\begin{array}{c}1 \% \mathrm{NaOH} \text { Extract } \\
(\%)\end{array}$ & $\begin{array}{c}\text { Cellulose } \\
(\%)\end{array}$ & $\begin{array}{c}\text { Lignin } \\
(\%)\end{array}$ & $\begin{array}{c}\text { Pentosan } \\
(\%)\end{array}$ \\
\hline Un-pretreated & - & 34.31 & 52.80 & 20.63 & 31.15 \\
\hline \multirow{2}{*}{8} & BW & 38.36 & 52.71 & 20.14 & 31.64 \\
\cline { 2 - 6 } & TW & 36.18 & 52.84 & 20.35 & 31.80 \\
\hline \multirow{2}{*}{16} & BW & 32.73 & 52.55 & 21.30 & 31.28 \\
\cline { 2 - 7 } & TW & 35.59 & 52.45 & 21.19 & 31.33 \\
\hline
\end{tabular}

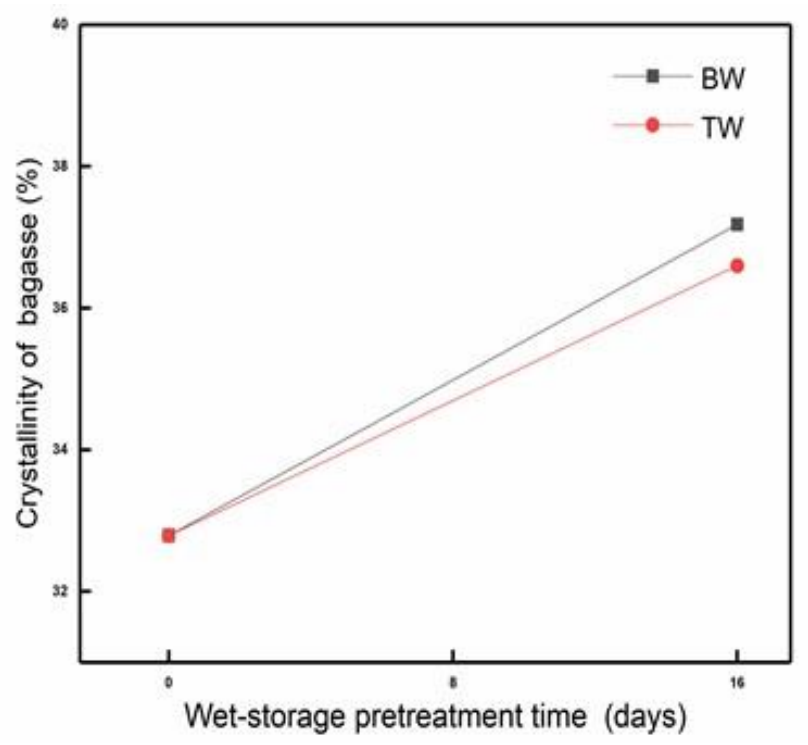

Fig. 3. The effect of wet-storage pretreatment on crystallinity of wet-storage pretreated bagasse

The solid content of the permeate indicated the amount of small molecular substances removed from the bagasse into the permeate during the wet-storage pretreatment. As shown in Fig. 4, the solid content of BW and TW increased rapidly at the beginning, then stabilized (around 8.0 of BW and 6.0 of TW).

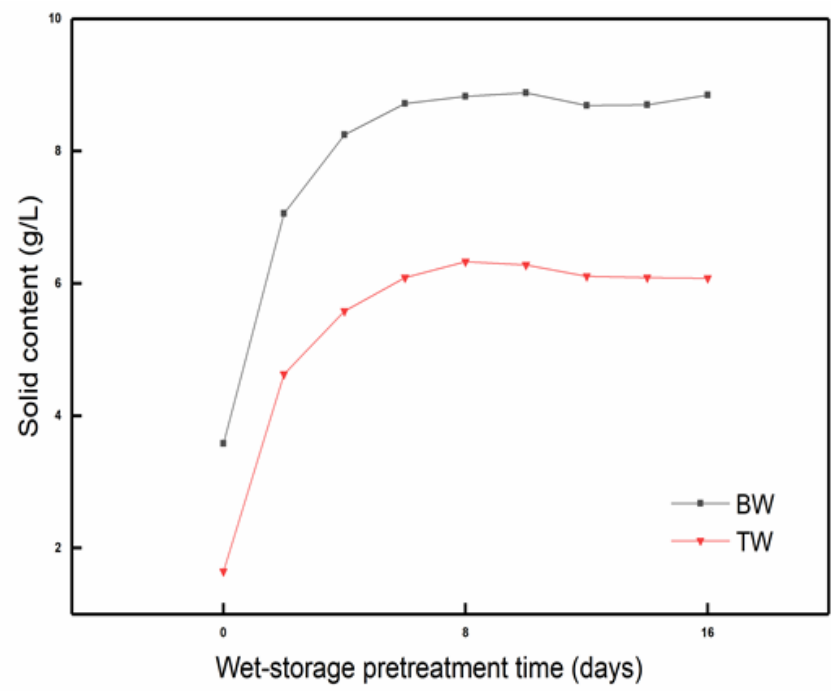

Fig. 4. Effect of wet-storage pretreatment on the solid content of permeate 
This rapid increase in the early stage of pretreatment was attributed to the decreased solids (cane, dust, and lignin small molecules) from the bagasse and dissolution of solids into permeate. With the increase of pretreatment time, the dissolution and degradation of small molecules reached dynamic equilibrium, leading to a stabilization of content.

When the pretreatment time was from 0 to $8^{\text {th }}$ day, the solid content increased from $3.58 \mathrm{~g} / \mathrm{L}$ to $8.83 \mathrm{~g} / \mathrm{L}$ for $\mathrm{BW}$, after that the solid content was stabilized at around $8.80 \mathrm{~g} / \mathrm{L}$. The solid content increased from $1.65 \mathrm{~g} / \mathrm{L}$ to $6.33 \mathrm{~g} / \mathrm{L}$ for TW, and then the solid content was stabilized at around $6.10 \mathrm{~g} / \mathrm{L}$. This indicated that the solution ability of BW was higher than that of TW.

\section{Effect of Wet-storage Pretreatment on the Property of Alkali-Oxygen Pulping of Bagasse}

The results of bagasse alkali-oxygen pulping indicated that the delignification selectivity was enhanced by wet-storage pretreatment, and the improvement of bagasse pretreated by BW was better than TW. As shown in Table 4, for the bagasse pretreated by BW, from 0 day to 16 days, the Kappa number of pulp was reduced by $11.54 \%$, and the viscosity was raised by $8.9 \%$. The decrease of Kappa number and the increase of viscosity also increased the screened pulp yield. For the bagasse pretreated by TW, although the screened pulp yield was raised, the Kappa number and viscosity were reduced, which indicates a bad effect for improving delignification selectivity.

Table 4. Effect of Wet-storage Pretreatment on the Alkali-Oxygen Pulping Property of Bagasse

\begin{tabular}{|c|c|c|c|c|}
\hline \multirow{2}{*}{$\begin{array}{c}\text { Wet-storage } \\
\text { Pretreatment Time } \\
\text { (days) }\end{array}$} & \multirow{2}{*}{$\begin{array}{c}\text { Pretreatment } \\
\text { Method }\end{array}$} & $\begin{array}{c}\text { Screened Pulp Yield } \\
(\%)\end{array}$ & $\begin{array}{c}\text { Kappa } \\
\text { Number }\end{array}$ & $\begin{array}{c}\text { Viscosity } \\
(\mathrm{mL} / \mathrm{g})\end{array}$ \\
\cline { 3 - 5 } & - & 58.75 & 15.16 & 805 \\
\hline Un-pretreated & BW & 59.90 & 16.52 & 860 \\
\hline \multirow{2}{*}{8} & TW & 58.42 & 15.83 & 827 \\
\cline { 2 - 5 } & BW & 62.67 & 13.41 & 877 \\
\cline { 2 - 5 } & TW & 59.99 & 13.63 & 747 \\
\hline
\end{tabular}

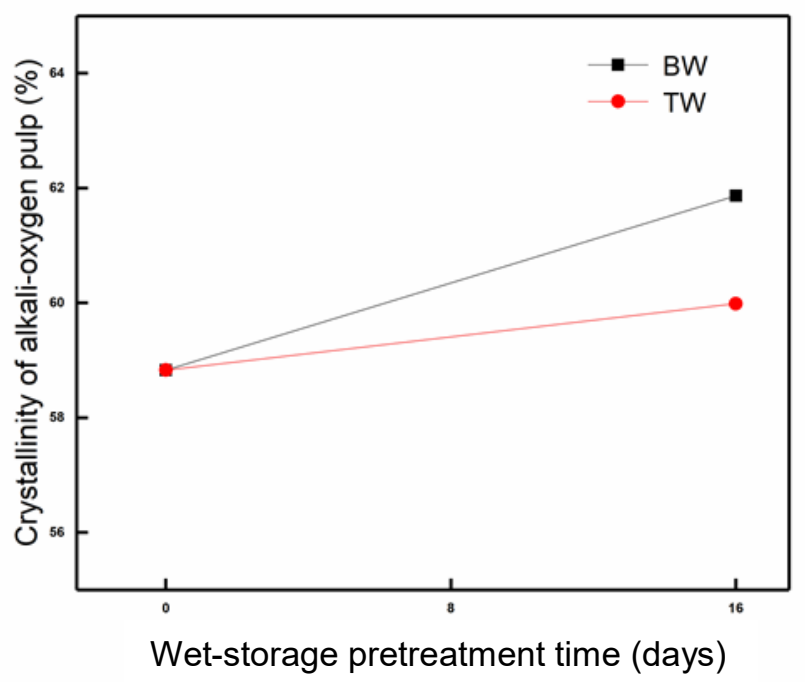

Fig. 5. The effect of wet-storage pretreatment on crystallinity of alkali-oxygen pulp 
As shown in Fig. 5, the crystallinity of pulp pretreated by BW was higher than by TW. Therefore, the property of BW pretreated bagasse alkali-oxygen pulping was the best in this study, and then that of TW, and both were better than that of un-pretreated bagasse. The results suggest that more cooking liquid permeated the inner cell wall structure of bagasse and reacted with lignin during the alkali-oxygen pulping process. The enhanced liquid permeability was attributable to the presence of oxygen in alkalioxygen pulping process; however, the increase of porosity and the change of chemical composition were the important reason for improving the delignification selectivity. The results demonstrated that the delignification selectivity was improved by wetstorage pretreatment. Furthermore, the pulp properties of BW pretreated bagasse was obviously better than that of TW pretreated bagasse. The selectivity and efficiency of delignification were increased by the enhanced liquid permeability, which led to the improvement in pulping. Han and Chen (2008) indicated that pulping properties were promoted when the bagasse raw materials were pretreated with alkali.

\section{CONCLUSIONS}

1. The effect of wet-storage pretreatment on enhancing delignification selectivity of the bagasse in alkali-oxygen pulping was studied.

2. After the bagasse pretreated by wet-storage, the inner structures of the cell wall were opened and porosity was increased. As a result, alkali impregnation effectiveness of the pretreated bagasse raw material was improved. Compared with tap water (TW) pretreatment, bleaching wastewater (BW) pretreatment provided advantages in improving liquid permeability, as much more molecular substance dissolved from bagasse during wet-storage by the residual chemicals in BW.

3. The bagasse wet-storage pretreated for 16 days was beneficial to alkali-oxygen pulping. The screened pulp yield and property of pulp were improved, resulting from the enhanced delignification selectivity and improved liquid permeability. The alkali-oxygen pulping property of BW pretreated bagasse was better that of TW.

\section{ACKNOWLEDGEMENTS}

The authors gratefully acknowledge the financial support from the National Natural Science Foundation of China (Grant No. 21466017 and 31460176).

\section{REFERENCES CITED}

Chen, K. L., Tosaka, K., and Hayashi, J. (1994). "Alkali-oxygen pulping of rice straw: two-storage pulping by alkali soaking and oxygen cooking," TAPPI Journal 77(7), 109-114.

Cui, Z., Shi, J., Wan, C., and Li, Y. (2012). "Comparison of alkaline-and fungiassisted wet-storage of corn stover," Bioresource Technology 109, 98-104. DOI: 10.1016/j.biortech.2012.01.037

Fu, T. K., Wei, X. Y., Li, J. H., and Wang, F. (2013). "Development of natural nanocellulose from tropical agriculture products," Journal of Cellulose Science and Technology 21(1), 78-85. DOI: 10.16561/j.cnki.xws.2013.01.001

Gullichsen, J. E., and Sundqvist, H. (1995). “On the importance of impregnation and 
chip dimensions on the homogeneity of kraft pulping," in: TAPPI Pulping Conference, Chicago, USA, pp. 227-234.

Han, S., and Chen, K. (2008). "Study on soda-oxygen pulping of bagasse with alkali pretreatment and black liquor back-cycling," in: International Papermaking and Environment Conference, Tianjin, China, pp. 387-390.

Hernández-Salas, J. M., Villa-Ramírez, M. S., Veloz-Rendón, J. S., Rivera-Hernández, K. N., González-César, R. A., Plascencia-Espinosa, M. A., and Trejo-Estrada, S. R. (2009). "Comparative hydrolysis and fermentation of sugarcane and agave bagasse," Bioresource Technology 100(3), 1238-1245. DOI: 10.1016/j.biortech.2006.09.062

Khakifirooz, A., Ravanbakhsh, F., Samariha, A., and Kiaei, M. (2012). "Investigating the possibility of chemi-mechanical pulping of bagasse," BioResources 8(1), 2130 .

Khristova, P., Kordsachia, O., Patt, R., Karar, I., and Khider, T. (2006). "Environmentally friendly pulping and bleaching of bagasse," Industrial Crops and Products 23(2), 131-139. DOI: 10.1016/j.indcrop.2005.05.002

Kurakake, M., Kisaka, W., Ouchi, K., and Komaki, T. (2001). "Pretreatment with ammonia water for enzymatic hydrolysis of corn husk, bagasse, and switchgrass," Applied Biochemistry and Biotechnology 90(3), 251-259.

Laser, M., Schulman, D., Allen, S. G., Lichwa, J., Antal Jr, M. J., and Lynd, L. R. (2002). "A comparison of liquid hot water and steam pretreatments of sugar cane bagasse for bioconversion to ethanol," Bioresource Technology 81(1), 33-44. DOI: 10.1016/S0960-8524(01)00103-1

Li, Z., Li, J., Xu, J., and Mo, L. H. (2015). "Clean bleaching engineering practice for bagasse pulp: Totally chlorine-free and elemental chlorine-free bleaching realized with the same production line," BioResources 10(2), 2667-2680.

Malkov, S., Tikka, P., and Gullichsen, J. (2001). "Towards complete impregnation of wood chips with aqueous solutions," Paperi ja Puu-Paper and Timber 83(8), 468-473.

Martín, C., Galbe, M., Nilvebrant, N. O., and Jönsson, L. J. (2002). "Comparison of the fermentability of enzymatic hydrolyzates of sugarcane bagasse pretreated by steam explosion using different impregnating agents," Applied Biochemistry and Biotechnology 98-100(1-9), 699-716.

Martínez, E. A., Silva, S. S., e Silva, J. B. A., Solenzal, A. I., and Felipe, M. G. (2003). "The influence of $\mathrm{pH}$ and dilution rate on continuous production of xylitol from sugarcane bagasse hemicellulosic hydrolysate by C. guilliermondii," Process Biochemistry 38(12), 1677-1683. DOI: 10.1016/S0032-9592(02)00244-3

Ogunsile, B. O., and Quintana, G. (2010). "Modeling of soda-ethanol pulps from Carpolobia lutea," BioResources 5(4), 2417-2430.

Rainey, T. J., and Clark, N. B. (2004). "An overview of bagasse as a resource for the Australian paper industry," Proceedings-Australian Society of Sugar Cane Technologists, Brisbane, Australia, Vol.26, 73-81.

Rocha, G. D. M., Gonçalves, A. R., Oliveira, B. R., Olivares, E. G., and Rossell, C. E. V. (2012). "Steam explosion pretreatment reproduction and alkaline delignification reactions performed on a pilot scale with sugarcane bagasse for bioethanol production," Industrial Crops and Products 35(1), 274-279. DOI: 10.1016/j.indcrop.2011.07.010

Sendelius, J. (2005). Steam Pretreatment Optimisation for Sugarcane Bagasse in Bioethanol Production, Master's Thesis, Department of Chemical Engineering, Lund University, Lund, Sweden.

Sridach, W. (2010). "The environmentally benign pulping process of non-wood 
fibers," Suranaree Journal of Science and Technology 17(2), 105-123.

TAPPI T17 wd-70 (1970). "Cellulose in wood," TAPPI Press, Atlanta, GA.

TAPPI T13 wd-74 (1974). "Lignin in wood," TAPPI Press, Atlanta, GA.

TAPPI T19 wd-71 (1971). "Pentosans in wood," TAPPI Press, Atlanta, GA.

TAPPI T236 om-13 (2013). "Kappa number of pulp," TAPPI Press, Atlanta, GA.

TAPPI T230 om-13 (2013). "Viscosity of pulp (capillary viscometer method)," TAPPI Press, Atlanta, GA.

TAPPI T4 wd-75 (1975). “One percent caustic soda solubility of wood," TAPPI Press, Atlanta, GA.

TAPPI T625 cm-14 (2014). "Analysis of soda and sulfate black liquor,” TAPPI Press, Atlanta, GA.

TAPPI T692 om-04 (2004). "Determination of suspended solids in kraft green and white liquors," TAPPI Press, Atlanta, GA.

Teixeira, L. C., Linden, J. C., and Schroeder, H. A. (1999). “Optimizing peracetic acid pretreatment conditions for improved simultaneous saccharification and cofermentation (SSCF) of sugar cane bagasse to ethanol fuel," Renewable Energy 16(1-4), 1070-1073. DOI: 10.1016/S0960-1481(98)00373-5

Vallejos, M. E., Zambon, M. D., Area, M. C., and da Silva Curvelo, A. A. (2012). "Low liquid-solid ratio (LSR) hot water pretreatment of sugarcane bagasse," Green Chemistry 14(7), 1982-1989. DOI: 10.1039/C2GC35397K

Vilay, V., Mariatti, M., Taib, R. M., and Todo, M. (2008). "Effect of fiber surface treatment and fiber loading on the properties of bagasse fiber-reinforced unsaturated polyester composites," Composites Science and Technology 68(3-4), 631-638. DOI: 10.1016/j.compscitech.2007.10.005

$\mathrm{Xu}$, E. C. (2001). "APMP pulps from non-wood fibres. Part 1: Kenaf and straw," Appita Journal 54(5), 444-448.

Yue, F., Chen, K. L., and Lu, F. (2016). "Low temperature soda-oxygen pulping of bagasse," Molecules 21(1), 85. DOI: 10.3390/molecules21010085

Zanuttini, M., Marzocchi, V., Citroni, M., and Mocchiutti, P. (2003). "Alkali impregnation of hardwoods. Part I: Moderate treatment of poplar wood," Journal of Pulp and Paper Science 29(9), 313-317.

Zhang, X. J., and Chen, K. L. (2007). "Study on the condition of bagasse oxygenalkali pulping," Paper and Paper Making 26, 29-31. DOI: 10.13472/j.ppm.2007.01.011

Zhu, S., Wu, Y., Yu, Z., Liao, J., and Zhang, Y. (2005). "Pretreatment by microwave/alkali of rice straw and its enzymic hydrolysis," Process Biochemistry 40(9), 3082-3086. DOI: 10.1016/j.procbio.2005.03.016

Article submitted: October 23, 2019; Peer review completed: April 10, 2020; Revised version received and accepted: May 13, 2020; Published: May 19, 2020.

DOI: $10.15376 /$ biores.15.3.5281-5290 